the period of ionium could at once be found. For example, if the period were 10o, ooo years, there should be $12^{\circ} 5$ grams of pure ionium per ton of uranium. Auer von Welsbach, in a masterly chemical separation of the rare-earth fraction from 30 tons of Joachimsthal pitchblende, separated a preparation, which he described as thorium oxide, containing ionium, the activity of which was measured by Meyer and von Schweidler. To obtain a maximum estimate for the period of ionium, I assumed that Welsbach's preparation was in reality pure ionium oxide (which it certainly was not, as it gave the thorium emanation), and so I obtained the period of a million years as the upper possible limit. In proportion as the percentage of ionium oxide present is less than roo per cent., this period must be reduced. ${ }^{2}$ Thus we have fixed the period of ionium as between $10^{-5}$ and $10^{-6}$ vears, if ionium is the only intervening long-lived member.

Quite recenty a method has been devised for calculating the period of ionium from the range of its a-particles, which is based upon an empirical mathematical relation holding between this range and the periods of the substances giving a-rays in the case of the other members of the series. ${ }^{3}$ The most recent estimate by this method is about 200,000 years, which may be accepted provisionally as the most probable at the present time. If this is correct, there should be 25 grams of ionium per ton of uranium in minerals. A variety of evidence thus leads to the conclusion that to detect the growth of radium from uranium either still larger quantities of uranium or still longer time is necessary. Even after ten years, that is, at the end of 1916 , if the period of ionium is as estimated, the uranium in No. III. preparation should only have produced $12 \times 10^{-12}$ grams of radium, which is rather less than half the amount that will then have been formed by the ionium initially present. Nos. I. and II. preparations are very much less favourable. But it is interesting to consider No. IV. preparation, which, though only $2^{\circ} 6$ years old, has more than seven times as much uranium as No. III. From the present slope of the curve it appears to have little more than one-half as much ionium, relatively to the uranium, as No. III., whereas the relative initial quantity of radium is about twice as great as in No. III. After eight years, that is in 1917 , the quantity of radium produced from the uranium should be about equal to that which will have by then been produced from the ionium present. A distinct upward slope should be detectable in the growth curve some time before this. But this is the best, if the estimate of the period of ionium assumed is correct, that the present set of experiments can offer to the solution of the problem. With the experience already gained, especially in dealing with large quantities of uranium and in the methods of measurements of the minutest quantities of radium, there should be no difficulty in obtaining and dealing with sufficient uranium, say 20 kilograms, of the requisite degree of purity as regards ionium and radium, to determine directly in a few years the period of ionium from the growth curve provided it is not greater than 200,000 years.

A favourable opportunity is being awaited to initiate this large-scale experiment. It requires a small room to itself in a permanent institution uncontaminated with radium, and some guarantee that once installed the preparations will remain undisturbed for a reasonable term of years, and that the measurements will be continued in a comparable manner should the period of life of the original investigator prove in-

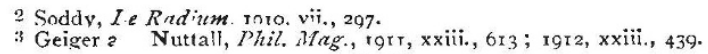
2217 , VOL. 89]
}

sufficient. It is not enough to set aside a quantity of uranium for our successors to see if any radium has grown in it. It is essential that the exact form of the growth curve should be known before the problem in question can be fully answered. There may be more than one long-lived intermediate product between uranium and radium. However, such indirect information as has been acquired as to the life period of ionium indicates that it alone is sufficient to account for the present results as regards the absence of growth of radium from uranium.

\section{THE CROCKER LAND EXPEDITION}

$R$ EFERENCE was made in Nature of February 22 (p. 560) to the expedition organised by the American Museum of Natural History and the American Geographical Society to reach and map Crocker Land, in the north polar seas north-west of Grant Land, and to make all the scientific studies en route and in other parts of the Arctic regions that circumstances may permit.

The expedition will leave Sydney, N.S., by special steamer about July 20, 1912 , and it is proposed to land on the south side of Bache Peninsula (Flagler Bay), lat. $70^{\circ}$ Io $^{\prime} \mathrm{N}$., and establish winter quarters. The ship will then be sent home. About the middle of September, sledging supplies to Cape Thomas Hubbard will be begun, and the work will be carried on throughout the winter during the moonlight periods. Cape Thomas Hubbard will be left with the return of dawn in February, 1913, and the expedition will push across the ice to Crocker Land. Crocker Land will be left about May $x$, and a return will be made to Cape Thomas Hubbard. Scientific work will be carried on in Grant Land and along the return route to winter quarters on Flagler Bay, where the expedition expects to arrive in Julv, 1913. In the spring and summer of I9It there will be an expedition from Whale Sound (Inglefield Gulf) directly eastward to the summit of the ice-cap of Greenland, at the widest part of that island. The return to New York will be in the autumn of I9I4 by special ship.

The leaders of the expedition will be Mr. George Borup, assistant curator of geology in the American Museum of Natural History, and Mr, Donald B. MacMillan, both of whom are well known by their work done under Admiral Peary in his last polar expedition.

It is estimated that not less than fifty thousand dollars (1o,oool.) should be provided for the absolute needs of the expedition, in order to enable it to accomplish the results that have been outlined above. On the proviso that sufficient funds are contributed from outside sources, the American Museum of Natural History has agreed to appropriate in the course of the expedition six thousand dollars in money, and has taken over its organisation and management. The American Geographical Society has made an appropriation of six thousand dollars toward the expedition, and Yale University an appropriation of one thousand dollars, while other subscriptions have been promised.

\section{UNIVERSITY AND EDIICATIONAL INTELLIGENCE.}

GLisGow.-The degree of Doctor of science was conferred upon the following on April 22 :- - Leonard Findlay: Thesis, "The Etiolory and Condition of the Blood in Spontaneous and Experimental Rickets, with additional papers." David Robertson : Thesis, "The Mathematical Design of Transformers; Electrical Meters on Variable Loads; and other original 
papers." George Duncan Campbell Stokes: Thesis, "A Critical Comparison of the Overlapping Section of the Oxford and Potsdam Astrographic Catalogues; An Original Solution of the Problem of Two Bodies; An Analytical Study of Plane Rolling Mechanisms."

Commemoration Day will be observed on June 25 . A meeting will be held in the Bute Hall, when Prof. F. O. Bower, F.R.S., will deliver an oration on "Sir Joseph Hooker," and honorary degrees will be conferred. It is expected that a number of the delegates attending the Congress of the Universities of the Empire will be present.

THE resignation is announced of Prof. Arthur Searle, Phillips professor of astronomy at Harvard University. Prof. Searle, who graduated from Harvard in 1856 , has taught in the Cniversity for fortytwo years.

A course of four lectures on "Heredity Considered from the Point of View of Physiology and tathology" will be delivered by Dr. F. W. Mott, F.R.S., in the Physiological Laboratory, King's College, on Mondays, May 20 and 27, and June 3 and 10, at 4.30 p.m. The lectures are free to members of King's College, London, to internal students of the Lniversity, and to medical men.

AT the celebration of the $75^{\text {th }}$ anniversary of the foundation of the University of Athens, on April Io, honorary degrees in medicine were conferred on Profs. von Behring (Marburg), Celli (Rome), Ehrlich (Frankfort), Exner (Vienna), Golgi (Pavia), Kronecker (Berne), Laudouzy (Paris), Richet (Paris), Sir Ronald Ross (Liverpool), Roux (Paris), Schulze (Würzburg), Weichselbaum (Vienna), and others. The degree of doctor of philosophy was conferred on Sir Donald MacAlister (Glasgow), Delbrück (Jena), Dörpfeld (Athens), Gubernatis (Rome), Harnack (Berlin), Kenyon (London), Mahaffy (Dublin), Wheeler (Berkeley), and others; and the degree of doctor of science on Profs. Depéret (Lyons), Halácsy (Vienna), Lacroix (Paris), Lepsius (Darmstadt), Partsch (Leipzig), and Philippson (Bonn).

THE programme of the annual conference of the Child-Study Society, to be held in the University of London on May 9-1r inclusive, is now available. The subject arranged for discussion is the health of the child in relation to its mental and physical development. The presidential address will be delivered on May c by Sir James Crichton Browne, F.R.S. Among papers to be read at the conference may be mentioned :--The influence of defects of hearing in relation to the mental and physical development of the child, by Dr. J. Kerr Love; the influence of defects of vision in relation to the mental and physical development of the child; by Mr. N. Bishop Harman; the tuberculous child, by Dr. Jane Walker; and mental hygiene in relation to the development of the child, by Dr. T. Hyslop. Fuller particulars of the meeting can be obtained from the secretary of the London Society, 90 Buckingham Palace Road, London, S.W.

THE Department of Agriculture and Technical Instruction for Ireland will conduct summer courses of instruction for teachers on July $2-26$ next, and on August 6-3r. Among the courses arranged for Julv we notice for teachers in day secondary schools and in technical schools a course in experimental science; for those in secondary schools only, one in domestic economy; and for domestic economy instructresses one in advanced cookery, housewifery, hygiene, and NO. 2217 , VOL. 89$]$ sick nursing. In August the courses will be concerned with practical mathematics and mechanics, handrailing, metal work, and rural science. Though most of the courses will be held in Dublin, some have been arranged for other important centres. Teachers desiring to take advantage of these courses must fill up and return the appropriate form of application so as to reach the offices of the department, Upper Merrion Street, Dublin, not later than April 30.

Attention was directed, in our issue of April 4 (vol. lxxxix., p. 129) to the opening to-morrow of the spinning section of the textile department of the University of Leeds by the Master of the Clothworkers' Company. The new extension is intended to afford facilities for instruction in the principles and theory of the manufacture of worsted yarns on the Continental system. To secure the most suitable equipment for this branch of technological teaching, textile institutes, spinning works, and conditioning laboratories in Belgium, France, Germany, and Switzerland were inspected, and a full inquiry was made as to the commercial value and technical nature of this system of worsted yarn construction. The extension has been designed by Mr. Paul Waterhouse, and erected at a cost of 5ool., making a total amount of 75,0ool. granted by the Clothworkers' Company for technical education in the textile industries and dyeing departments of the Leeds University.

\section{SOCIETIES AND ACADEMIES.}

\section{LONDON.}

Zoological Society, April 2.-Dr. A. Simith Woodward, F.R.S., vice-president, in the chair.-R. I. Focock: A rare stag (Cervus wallichii) from Nepal, recently presented to the Zoological Society by his Majesty King George. The author pointed out the distinctive peculiarities of this species, which, on account of its great scarcity, had never been satisfactorily classified since it was described by G. Cuvier in ${ }^{1825}$ from a coloured illustration of a specimen living at that time in the Barrackpoor Menagerie. F. E. Beddard: Species of tapeworms of the genus Inermicapsifer obtained from the hyrax, with notes on the genera Zschokkeella and Thysanotænia. An account of the structure and characters of the species was given, together with the description of a new genus and two new species.-Dr. Bashford Dean : Living specimens of the Australian lung-fish (Ceratodus forsteri) in the society's collection. This paper contained some further observations made by the author in June, IgII, supplementary to his previous communication published in 1906, and dealt with the coloration, size, and age of the specimens. Details of the rate of growth of this species were also given, with notes on their method of breathing, their food, and an account of the regeneration of a portion of the left ventral fin which had suffered an injury.

Royal Astronomical Society, April 12.--Dr. Dyson, F.R.S., president, in the chair.-E. E. Barnard : Recent observations of Nova Cygni (1876). A series of measures of stars in the neighbourhood showed little evidence of motion; the nova seemed to have become stationary in brightness.-E. E. Barnard : Micrometrical measures and focal peculiarities of Nova Lacertæ, (Espin). Photographs were shown, from which it appeared that the nova existed as a 13th mag. star in 1803.-H. F. Newall: Photographs of the spectrum of Nova Geminorum (Enebo) made 